\title{
Postmortem interval estimation based on Chrysomya albiceps (Diptera, Calliphoridae) in a forensic case in the Andean Amazon, Caquetá, Colombia
}

\author{
Yardany RAMOS-PASTRANA ${ }^{1,2^{*}}$, Marta WOLFF ${ }^{2}$ \\ 1 Universidad de la Amazonia, Laboratorio de Entomología, Grupo de Investigación en Entomología - GIEUA, Centro de Investigaciones - INBIANAM, Florencia, Caquetá, Colombia \\ 2 Universidad de Antioquia, Instituto de Biología, Grupo de Entomología - GEAU, Medellín, Colombia \\ *Corresponding author: ya.ramos@udla.edu.co
}

\section{ABSTRACT}

This is the first application of forensic entomology in a case involving a human corpse found in the urban area of the Municipality of Florencia, Caquetá, Colombia, in the Piedemont of the Colombian Amazon. Three days after removing the body from the scene, pupae and puparia were collected and identified as Chrysomya albiceps (Wiedemann, 1819) (Diptera, Calliphoridae). The postmortem interval was estimated on the basis of previously published data and verified through accumulated degree hours $(\mathrm{ADH})$ and intrapuparial development. The estimated minimum postmortem interval was of 229 hours (9.5 days).

KEYWORDS: forensic science, carrion insetcs, death time, Amazon rainforest

\section{Intervalo pós-morte estimado a partir de Chrysomya albiceps (Diptera, Calliphoridae) em um caso forense na Amazônia Andina, Caquetá, Colômbia}

\begin{abstract}
RESUMO
Esta é a primeira aplicação da entomologia forense em um caso envolvendo um cadáver humano encontrado em uma área urbana do Município de Florencia, Caquetá, Colombia, no Piedemonte da Amazônia Colombiana. Três dias após a remoção do corpo da área, pupas e pupários foram coletados e identificados como Chrysomya albiceps (Wiedemann, 1819) (Diptera, Calliphoridae). O intervalo pós-morte (IPM) foi estimado com base em dados publicados previamente e verificado usando graus-horas acumulados (GHA) e desenvolvimento intrapuparial. O intervalo pós-morte mínimo estimado foi de 229 horas (9.5 dias).
\end{abstract}

PALAVRAS-CHAVE: ciência forense, insetos necrófagos, tempo de morte, floresta amazônica 
Forensic entomology is the science that uses information about insects and other arthropods, as well as their developmental cycle, to answer questions in criminal investigations (Catts and Goff 1992). The use of insects to estimate the postmortem interval (PMI) has been well established in several countries (Pujol-Luz et al. 2008), through either case reports or studies on the fauna associated to corpses. In Colombia, many studies have been conducted in the last decade on the entomofauna that live on carcasses (Wolff et al. 2001; Vélez and Wolff 2008; Ramos-Pastrana et al. 2014), but this data has not been used in human cases so far. The current study is the first in the Colombian Amazon Piedemont to estimate postmortem interval based on Chrysomya albiceps on a human corpse.

The use of forensic entomology is recommended by the United Nations (UN 1990), and it could greatly aid the judicial system in Colombia. It is used and accepted in different countries as a science that can aid in criminal investigations (Anderson 1997), especially when the corpse is in an advanced state of decomposition and it is not possible to determine the time of death using traditional methods. Therefore, determination of time of death is the main and most important goal of forensic entomology (Catts and Haskell 1990).

Diptera is often the first group of organisms to reach a corpse, so it is widely used to aid in criminal cases (Arnaldos $e t$ al. 2005). Within Diptera, species of the family Calliphoridae have frequently been reported as colonizers of carcasses, arriving on the early stages of decomposition (Gunn 2009). Chrysomya albiceps (Wiedemann 1819) is considered one of the main species of forensic importance due to its early presence on the corpse and high reproductive rate (Vásquez and Liria 2012). This African species was reported in the Neotropics in the late 1970s, initially in Brazil (Guimarães et al. 1978), then in Argentina, Paraguay (Mariluis 1983), Peru (Baumgartner and Grenberg 1985), and Colombia (RamosPastrana et al. 2014). It is nowadays considered to have a worldwide distribution (Grassberger $e t$ al. 2003), which has allowed the use of this species in a variety of important studies because it is easy to collect and to keep under laboratory conditions (Vélez and Wolff 2008; Pujol-Luz and BarrosCordeiro 2012).

On August $17^{\text {th }}, 2008$, at 3:00 pm, the corpse of an adult male was found on the outskirts of the city of Florencia, Department of Caquetá, Colombia (0136'09.6”N, $075^{\circ} 35^{\prime} 07.0^{\prime \prime} \mathrm{W}$ ) (Figure 1), in the Piedemont area between the Eastern Cordillera and the Amazon lowland. This area is located at 242 masl, with an average temperature of 25 ${ }^{\circ} \mathrm{C}, 80 \%$ relative humidity, and average annual rainfall of $3840 \mathrm{~mm}$ (IGAC 2010). The body was found in an area with herbaceous and bushy vegetation, partially exposed to sunlight, and $30 \mathrm{~m}$ away from a highway. The corpse was wearing jeans, rolled up to the knees, and a short-sleeve shirt. The head was in the skeletonized phase, and the trunk and extremities were in the active decay phase, without

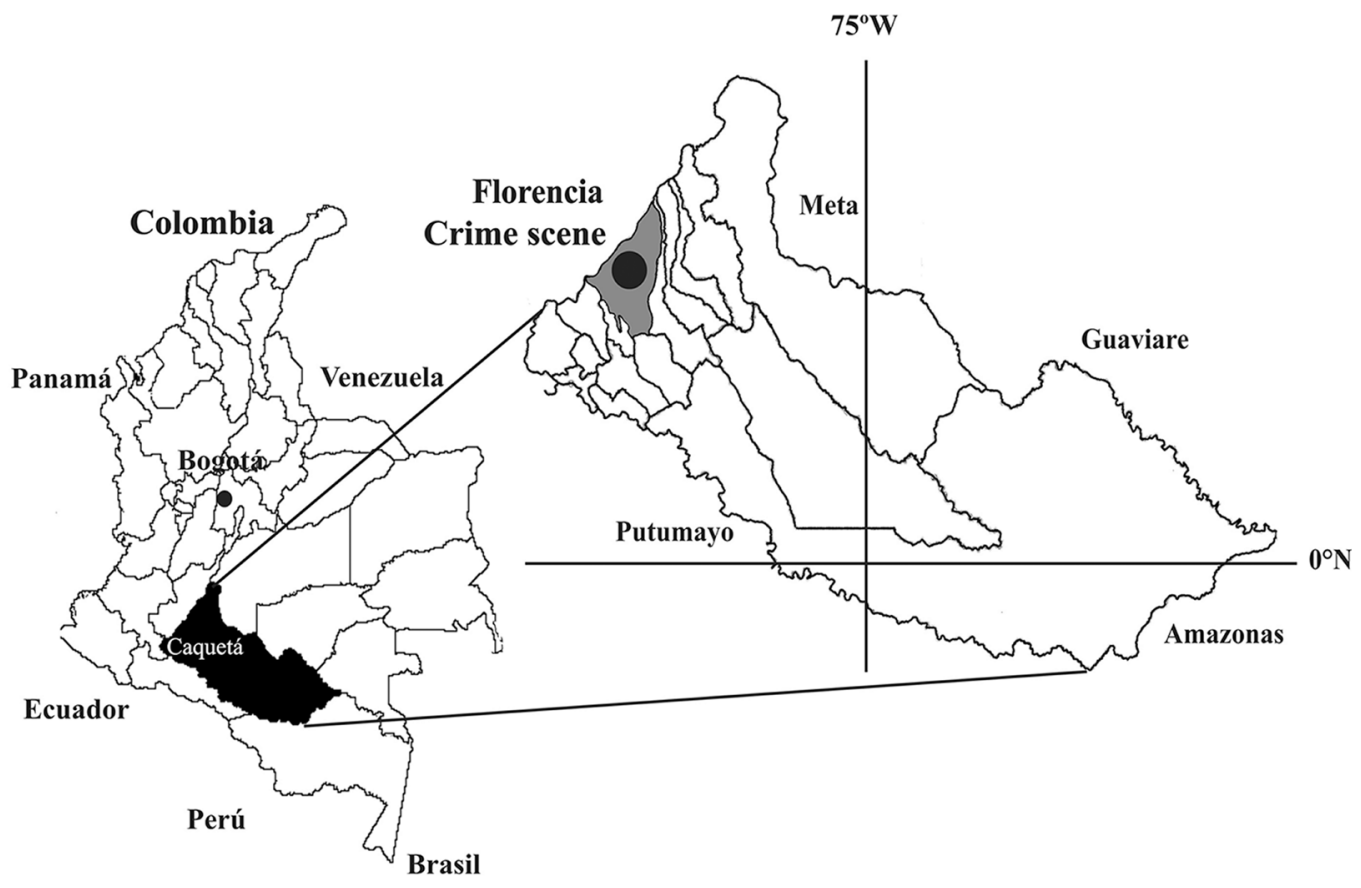

Figure 1. Geographical location of the crime scene in the Caquetá department, Colombia. 
alterations caused by vertebrate scavengers. The victim had a stab wound on the throat, which was confirmed as the cause of death during autopsy. The difference in degree of decomposition between the head and the rest of the body is explained by the slightly softer tissue of the head, and by the high insect colonization in natural orifices (i.e. eyes, mouth, nose and ears) and in external wounds during the early stages of decomposition (Amendt et al. 2004). Furthermore, the intrinsic factors associated to body decomposition processes should be considered as well, since they often cause the overlap of several decomposition stages on different parts of the body (Campobasso et al. 2001).

During the technical inspection of the body on the scene, there were no entomologists present to collect the insects, which were only obtained three days later, on August $20^{\text {th }}$, 2008. The scene remained undisturbed during the period until the insect sampling was performed by an entomologist (Y. Ramos) and other forensic specialists who collected 87 puparia of $C$. albiceps, of which 53 were empty. This species is the only recorded for Chrysomya in this region (RamosPastrana et al. 2014).

Most of the entomological evidence was fixed in $80 \%$ ethanol, packaged, and labeled according to norms issued by the Attorney General's Office and under the chain of custody code No. 80036. Ten puparia were kept alive in chambers at ambient temperature, emerging as adults in the same day they were collected (August 20 $0^{\text {th }}$ ) (Figure 2A). From the ethanol-fixed specimens, five puparia were dissected to study the intrapuparial development (Figure 2B) (Pujol-Luz and Barros-Cordeiro 2012). Species were identified with the keys proposed by Flórez and Wolff (2009) and Almeida and Mise (2009). All entomological material was deposited in the
Collection of Entomology/Laboratory of Entomology of the University of Amazonia (LEUA).

Pupation and emergence of C. albiceps occurred at 25.30 $\pm 3.26^{\circ} \mathrm{C}$ and after 8-10 and 13-14 days, respectively (Velez and Wolff 2008). The temperature at the crime scene during the days before discovering the body was within the abovementioned range. Based on Amendt et al. $(2007,2011)$, which require identification of the age of the immature stages of necrophagous flies (i.e. C. albiceps), the PIA (period of insect activity) in this case suggests that the species colonization occurred at two different times: oviposition I (based on empty puparia) on August $8^{\text {th }}$, and oviposition II (dissected puparia showing pharate adult with red eyes) on August $13^{\text {th }}$.

The accumulated degree hours (ADH) method was also used (Goff 2001) and based on temperature data supplied by the Instituto de Hidrología, Meteorología y Estudios Ambientales de Colombia (IDEAM). Based on a minimum threshold of $10{ }^{\circ} \mathrm{C}$ (Marchenko 1985; Kosmann et al. 2011 ), we concluded that $C$. albiceps requires $7,893 \mathrm{ADH}$ to develop from egg to adult $\left(312 \mathrm{~h} \times 25.30 \pm 3.26{ }^{\circ} \mathrm{C}=7,893\right.$ ADH). ADH from August $9^{\text {th }}$ until August $20^{\text {th }}$ was $7,337.4$ (Table 1). Thus, there were still 555.6 ADH missing for the minimum $\mathrm{ADH}$ required by $C$. albiceps to complete its life cycle. Dividing $555.6 \mathrm{ADH}$ by $25.4^{\circ} \mathrm{C}$ (average temperature on August $8^{\text {th }}$ ) we obtained 21.87, concluding that insect activity started on August $8^{\text {th }}$ around 2:00 am. Therefore, the two methods confirmed that the minimum PMI was of 229 hours (9.5 days) from corpse discovery until oviposition I, indicating that the probable date of oviposition was on August $8^{\text {th }}, 2008$ (Figure 3).

These estimates confirmed that adult emergence of $C$. albiceps, at an average temperature of $25.30^{\circ} \mathrm{C}$, occurred
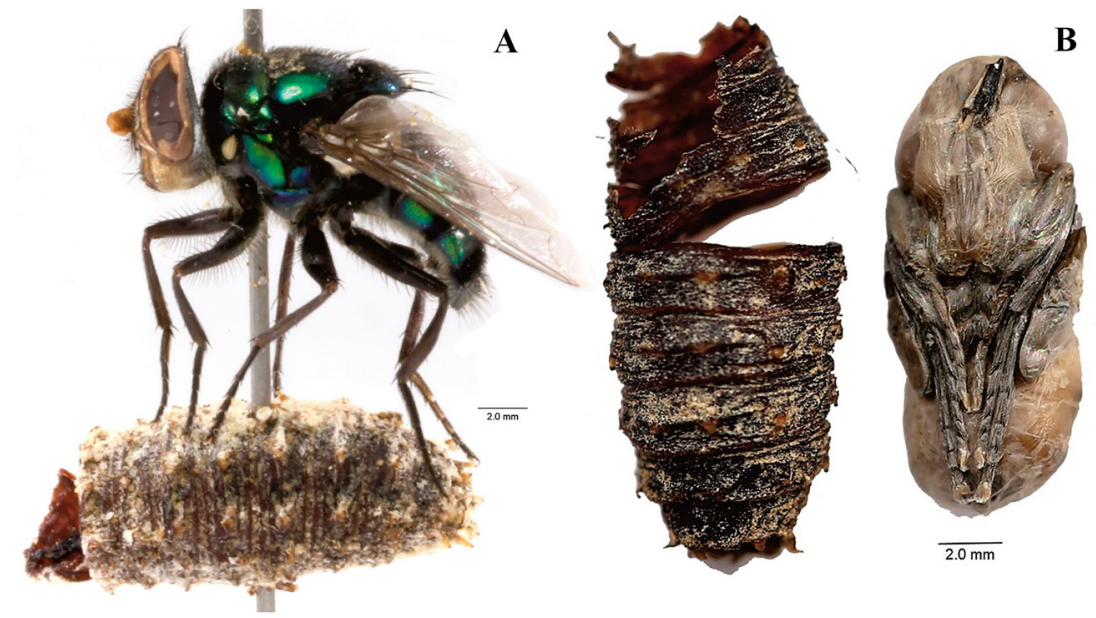

Figure 2. A - Adult of Chrysomya albiceps obtained from the puparium collected on the crime scene. B - Pharate adult in ventral view, with red eyes, dissected of pupa collected at the crime scene. This figure is in color in the electronic version. 
Table 1. Calculation of Accumulated Degrees Hours (ADH) at the study site in Florencia (Caquetá, Colombia)

\begin{tabular}{lclc}
\hline Data & Hours/Average daily temperature & & ADH \\
\hline 20 August & $15 \mathrm{~h} \times 26.6^{\circ} \mathrm{C}$ & $=$ & $399 \mathrm{ADH}$ \\
19 August & $24 \mathrm{~h} \times 27^{\circ} \mathrm{C}$ & $=$ & $648 \mathrm{ADH}$ \\
\hline 18 August & $24 \mathrm{~h} \times 23.5^{\circ} \mathrm{C}$ & $=$ & $564 \mathrm{ADH}$ \\
17 August & $24 \mathrm{~h} \times 28^{\circ} \mathrm{C}$ & $=$ & $672 \mathrm{ADH}$ \\
16 August & $24 \mathrm{~h} \times 28.9^{\circ} \mathrm{C}$ & $=$ & $693.6 \mathrm{ADH}$ \\
15 August & $24 \mathrm{~h} \times 26.7^{\circ} \mathrm{C}$ & $=$ & $640.8 \mathrm{ADH}$ \\
14 August & $24 \mathrm{~h} \times 26.4^{\circ} \mathrm{C}$ & $=$ & $633.6 \mathrm{ADH}$ \\
13 August & $24 \mathrm{~h} \times 23.2^{\circ} \mathrm{C}$ & $=$ & $556.8 \mathrm{ADH}$ \\
\hline 12 August & $24 \mathrm{~h} \times 28.9^{\circ} \mathrm{C}$ & $=$ & $693.6 \mathrm{ADH}$ \\
11 August & $24 \mathrm{~h} \times 27.5^{\circ} \mathrm{C}$ & $=$ & $660 \mathrm{ADH}$ \\
10 August & $24 \mathrm{~h} \times 24.4^{\circ} \mathrm{C}$ & $=$ & $585.6 \mathrm{ADH}$ \\
09 August & $24 \mathrm{~h} \times 24.6^{\circ} \mathrm{C}$ & $=$ & $590.4 \mathrm{ADH}$ \\
\hline Total ADH & & & $7.337,4 \mathrm{ADH}$ \\
\hline
\end{tabular}

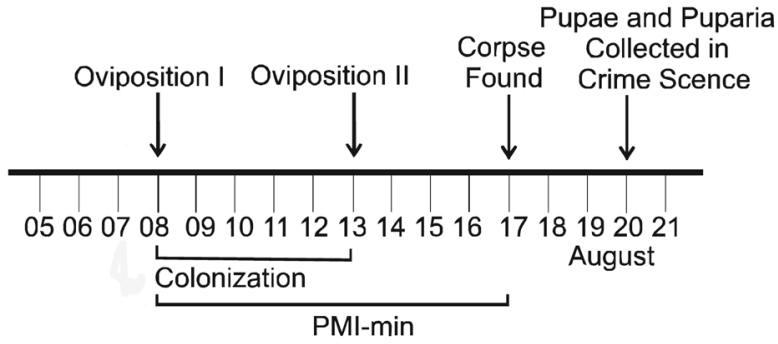

Figure 3. Time line showing events: date body found (August 17); samples collected and fixed puparia and empty pupa (August 20), oviposition I, empty puparium (August 8), oviposition II, pupa, adult pharado Red Eye (August 13). Estimated minimum PMI (August 8).

within the time interval calculated by Velez and Wolff (2008), i.e., 13-14 days. Unfortunately, this case was filed as unresolved, as are most cases occurring in Colombia, since the murderer was not caught in the act, demonstrating the need to strengthen the institutions and personnel responsible for conducting criminal investigations in this country.

Caution is required when linking PIA time to PMI, especially in cases where the corpse has been buried in hermetic places, since insect colonization is delayed in these circumstances, and the PIA could be shorter than the PMI. If the person had myiasis, with larvae that were feeding on living tissues, and continuing to do so on necrotic tissue after death, the PIA could be longer than the PMI (Catts and Haskell 1990; Amendt et al. 2007). However, in the current case, the PIA and the minimum PMI determined by the age of the immature insects (larvae and pupae), or by the presence of empty puparia and/or activity on the body using $\mathrm{ADH}$ methods, were the same.

Although the entomological evidence was obtained three days after removing the corpse from the crime scene, it was still possible to recover specimens that provided valuable information on the case, even in the absence of the corpse. Although the removal could have affected the development of $C$. albiceps, this was not the case since the specimens used for the PMI estimation were in the pupal stage and under the substrate. It should be noted that entomological evidence must be gathered from the whole scene and not just from the body (Campobasso et al. 2001). This case illustrates the difficulties encountered in the application of forensic entomology in Colombia, demonstrated by the lack of trained personnel and appropriate material sampling when the corpse was discovered, and by the disregard of the calculated PIA and PMI times in the investigation of this criminal case.

\section{ACKNOWLEDGEMENTS}

The authors were funded by Universidad de la Amazonia and the Colciencias Project 601-2009. We are thankful to the Attorney General's Office of Colombia for authorizing the publication of this case and biologists Carlos Londoño and Julian Penagos for the edition of the figures.

\section{REFERENCES}

Almeida, L.M.; Mise, K.M. 2009. Diagnosis and key of the main families and species of South American Coleoptera of forensic importance. Revista Brasileira de Entomologia, 53: 227-244.

Amendt, J.; Krettek, R.; Zehner, R. 2004. Forensic entomology. Naturwissenschaften, 91: 51-65.

Amendt, J.; Campobasso, C.P.; Gaudry, E.; Reiter, C.; Le Blanc, H.H.; Hall, M.J.R. 2007. Best practice e in forensic entomology - standards and guidelines. International Journal of Legal Medicine, 121: 90-104.

Amendt, J.; Richards, C.S.; Campobasso, C.P.; Zehner, R.; Hall, M.J.R. 2011. Forensic Entomology: applications and limitations. Forensic Science, Medicine and Pathology, 7: 379-392.

Anderson, G.S. 1997. The use of insects to determine of decapitation: a case study from British Columbia. Journal of Forensic Science, 42: 947-950.

Arnaldos, M.I.; García, M.D.; Romera, E.; Presa, J.J.; Luna, A. 2005. Estimation of postmortem interval in real cases based on experimentally obtained entomological evidence. Forensic Science International, 149: 57-65.

Baumgartner, D.L.; Greenberg, B. 1985. Distribution of medical ecology of the blowflies (Diptera: Calliphoridae) of Perú. Annals of the Entomological Society America, 78: 565-587.

Campobasso, C.P.G.; Di Vella, G.; Introna, F. 2001. Factors affecting decomposition and Diptera colonization. Forensic Science International, 120: 18-27. 
Catts, E.P.; Haskell, N.H. 1990. Entomology and Death a procedural guide. USA, South Carolina, Joyce's Print Shop, Inc, Clemson, 182p.

Catts, E.P.; Goff, M.L. 1992. Forensic entomology in criminal investigations. Annual Review Entomology, 37: 253-272.

Flórez, E.; Wolff, M. 2009. Descripción y Clave de los Estadios Inmaduros de las Principales Especies de Calliphoridae (Diptera) de Importancia Forense en Colombia. Neotropical Entomology, 38: 418-429.

Goff, M.L. 2001. A Fly for the Prosecution, How Insects Evidence Helps Solve Crimes. Harvard University Press, Cambridge, 240p.

Grassberger, M.; Friedrich, E.; Reiter, C. 2003. The blowfly Chrysomya albiceps (Wiedemann) (Diptera: Calliphoridae) as a new indicator in Central Europe. International Journal of Legal Medicine, 117: 75-81.

Guimarães, J.H.; Prado, A.P.; Linhares, A.X. 1978. Three newly introduced blowfly species in southern Brazil (Diptera: Calliphoridae). Revista Brasileira de Entomologia, 22: 53-60.

Gunn, A. 2009. Essential Forensic Biology. 2nd ed. Wiley-Blackwell Liverpool, Jhon Moores University, Liverpool, 440p.

I.G.A.C. Instituto Geográfico Agustín Codazzi. 2010. Caquetá. Características geográficas. Subdirección de Geografia y Cartografia, Bogotá, D.C. 556p.

Kosmann, C.; Macedo, M.P.; Barbosa, T.A.F.; Pujol-Luz, J.R. 2011. Chrysomya albiceps (Wiedemann) and Hemilucilia segmentaria (Fabricius) (Diptera, Calliphoridae) used to estimate the postmortem interval in a forensic case in Minas Gerais. Revista Brasileira de Entomologia, 55: 621-623.

Marchenko, M.I. 1985. Characteristic of development of the fly Chrysomya albiceps (Diptera, Calliphoridae). Entomologisches-koe Obozrenie, 64: 79-84.
Mariluis, J.C. 1983. Presencia del género Chrysomya en la región neotropical (Calliphoridae, Chrysomyiinae, Chrysomyiiniii). Revista de la Sociedad Entomológica Argentina, 42: 141-142.

ONU, Organización de las Naciones Unidas. 1990. Manual sobre la prevención e investigación eficaces de las ejecuciones extralegales, arbitrarias o sumarias. New York. Oficina de las Naciones Unidas en Viena. Centro de Desarrollo Social y Asuntos Humanitarios, p.84.

Pujol-Luz, J.R.; Francez, P.A.C.; Ururahy-Rodrigues, A.; Constantino, R. 2008. The black soldier-fly, Hermetia illucens (Diptera, Stratiomyidae), used to estimate the postmortem interval in a case in Amapá State, Brazil. Journal of Forensic Science, 53: 476-478.

Pujol-Luz, J.R. \& K.B. Barros-Cordeiro. 2012. Intra-puparial development of females of Chrysomya albiceps (Wiedemann) (Diptera, Calliphoridae). Revista Brasileira de Entomologia, 56: 269-272.

Ramos-Pastrana, Y.; Velasquez-Valencia, A.; Wolff, M. 2014. Preliminary study of insetcs associated body decay in Colombia. Revista Brasileira de Entomologia, 58: 326-332

Vásquez, M.; Liria, J. 2012. Morfometría geo métrica alar para la identificación de Chrysomya albiceps y C. megacephala (Diptera: Calliphoridae) de Venezuela. Revista de Bióloga Tropical, 60: 1249-1258.

Vélez, M.C.; Wolff, M. 2008. Rearing five species of Diptera (Calliphoridae) of forensic importance in Colombia in semicontrolled field conditions. Papéis Avulsos de Zoologia, 48: 41-47.

Wolff. M.; Uribe, A.; Duque, P. 2001. A preliminary study of forensic entomology in Medellín, Colombia. Forensic Science International, 120: 53-59.

Received: 22/03/2017

Accepted: 10/08/2017 
